\title{
The dark side of effectuation in a Key Account Management relationship
}

Authors:

Dr Phillip McGowan, Senior Teaching Fellow, University of Portsmouth

Dr Chris Simms, Reader in Innovation Management and New Product Development, University of Portsmouth

Professor David Pickernell, Professor of Small Business and Enterprise Development, University of Portsmouth

Konstantios Zisakis, Research Fellow, University of Portsmouth

Corresponding Author: Phillip McGowan

Institution: University of Portsmouth

Address: Richmond Building, Portland Street, Portsmouth PO1 3DE

Telephone number: +44 (0)2392084 4820

Email address: phillip.mcgowan@port.ac.uk 


\title{
The dark side of effectuation in a Key Account Management relationship
}

\begin{abstract}
Purpose: The purpose of this paper is to consider the impact of effectuation when used by small suppliers within Key Account Management relationships.

Design/methodology/approach: An exploratory longitudinal case study approach was used to examine a single small supplier operating in the snack foods sector of the UK foods industry, as it entered into a new Key Account Management relationship with a major retailer and undertook four new product development projects.
\end{abstract}

Findings: Findings suggest effectuation may positively moderate the ability of a small supplier to enter into a Key Account Management relationship by enabling it to obtain resources and limit risk. However, once within the relationship, the use of effectuation may negatively impact success by increasing potential for failure to co-create new product development, leading to sub-optimal products, impacting buyer confidence and trust. Furthermore, a failed Key Account Management relationship may impact other customers through attempts to recover revenues by selling these products, which may promote short term success but, in the long-term, lead to cascading sales failure.

Research limitations/implications: It cannot be claimed that findings of just one case study represent all small suppliers or Key Account Management relationships. Furthermore, the case presented specifically concerns buyer-supplier relationships within the food sector.

Practical implications: This study appears to suggest caution be exercised when applying effectuation to enter into a Key Account Management relationship, as reliance on effectual means to garner required resources may lead to production of sub-optimal products, which are rejected by the customer. Additionally, a large customer considering entering into a 
Key Account Management relationship with a small supplier should take care to ensure their chosen partner has all resources needed to successfully deliver as required, or be prepared to provide sufficient support to avoid production of sub-optimal products.

Originality/value: Findings suggest use of effectuation within a Key Account Management relationship has potential to develop a dark side within business-to-business buyer-supplier relationships through unintentional breaches of trust by the selling party.

Key Words: Key Account Management, New Product Management, SME, Effectuation, Sales Failure, Small Supplier, Large Customer. 


\section{The dark side of effectuation in a Key Account Management relationship}

\section{Introduction}

It would appear axiomatic that failure to meet customers' expectations leads to sales failure (McGowan, 2020a). In the business-to-business (B2B) context, the gatekeeper role the "customer" business plays complicates this, often determining whether the final consumer is actually reached. To avoid this failure, Key Account Management (KAM) related literature recommends that products and services, and buyer-supplier relationships, be adapted to address both buyer needs/problems, and final customer's expectations (Davies \& Ryals, 2014; Weitz, Sujan, \& Sujan, 1986).

From supplier perspectives, KAMs relationship may drive innovation, relationship development and enhance access to senior management, leading to future planning supporting development of sustainable competitive advantage (La Rocca, Moscatelli, Perna, $\&$ Snehota, 2016). For buyers, these activities provide access to supplier innovation and additional resources to be exploited. Moreover, by engaging in KAM relationships, buyers may also prevent competitors gaining access to supplier innovation, securing a commercial advantage (Schiele, 2012). Such interaction may affect both the wider network and business landscape within which both selling and buying firms exist (Hakansson, Ford, Gadde, Snehota, \& Waluszewski, 2009; Håkansson \& Snehota, 2006).

The specific objective of many KAM relationships is to provide deeper levels of buyer-supplier integration. This can lead to co-created innovative solutions and mutual value creation delivering greater, longer-term, beneficial results (Davies \& Ryals, 2014; Friend, Curasi, Boles, \& Bellenger, 2014; Friend \& Johnson, 2014).

This paper considers how use of effectuation in KAM relationships adds an additional dimension, which can exacerbate potential for detrimental outcomes for effectuating small 
suppliers. It seeks to extend McGowan (2020b), published in the Journal of Business and Industrial Marketing (in press), by further investigating the efficacy and limitations of effectuation when applied by a resource restricted small supplier to facilitate sales beyond those that could be achieved using only their internal resources. This helps close an important gap in current literature, as hitherto, KAM relationships have been considered the domain of large companies because they require significant long-term commitment and investment (Ivens \& Pardo, 2016).

Indeed, the resources required is a potential barrier preventing small suppliers entering into such sales relationships. Drawing on existing literature (Dew, Sarasvathy, Read, \& Wiltbank, 2009; Roach, Ryman, \& Makani, 2016; Sarasvathy, 2009) effectuation in this study is defined as a decision making logic, by which a set of given resources (either controlled or available) are applied to an opportunity, to achieve the best possible (though not necessarily optimal) way to meet that opportunity, within the restrictions imposed by those resources.

This paper proceeds as follows. First, it analyses the relevant literature, identifying the key principles used in the study. This leads to development of propositions capturing the influence of effectual thinking in a resource constrained small supplier who enters into a KAM relationship. The longitudinal single case study approach uses data from a single firm within the consumer-packaged foods sector. Findings have implications for managers of small suppliers attempting to enter into a KAM relationship, and for KAM buyers themselves dealing with small, resource constrained suppliers, who adopt effectuation.

\section{Background Literature}

Effectuation logic, used in this paper, is based upon five principles providing the framework for decision-making: 
1. Means are resources of "who I am", "what I know" and "whom I know" (Sarasvathy, 2001b, p. 78), called 'means' because they are readily available to the entrepreneur.

2. Partnership, is the desire and ability to share both opportunity and risk in the venture (Sarasvathy, 2009), or create new opportunity by recruiting a partner (Welter, Mauer, \& Wuebker, 2016).

3. Leverage contingency, is the ability to welcome problems as opportunities and change business direction to gain the best possible advantage.

4. Affordable loss, is time and money available that may be lost without causing absolute failure of the venture (Sarasvathy, 2009). When faced with an investment decision where overall return on investment is unclear, a small firm owner-manager may choose to consider the downside of the decision, specifically the impact to the venture should the investment decision lead to loss. Affordable loss provides a useful lens through which ownermanagers of small firms may be more able to commit to action, knowing the risk is controlled, reduced to one that is affordable (Dew et al., 2009).

5. Control the controllable. In situations of uncertainty the decision maker may not be able to shape or control everything that may impact their decision. Effectuation logic posits that the entrepreneur identify, then focus on the elements of the environment that can be partially or fully controlled (Sarasvathy, 2009).

Effectuation has been posited as one way firms overcome resource restrictions and uncertainty (Sarasvathy, 2001). Personal means (both possessed and acquirable), skills and knowledge are combined to create an opportunity or solution (Sarasvathy, 2009). Extant literature suggests use of effectuation may positively impact inter-firm buyer-supplier relationships (McGowan, 2018, 2020b; Read, Dew, Sarasvathy, Song, \& Wiltbank, 2009; 
Sarasvathy, 2009). This suggests application by small suppliers could be appropriate and facilitate entry into KAM relationships, to undertake New Product Development (hereafter NPD) to create sales opportunity with larger customers (McGowan, 2018; Ortega, García, \& Santos, 2017; Sarasvathy, 2009; Wu, Liu, \& Su, 2020). Effectuation is, however, different to causal logic, which is more readily used in large firms (Sarasvathy, 2009).

While effectuation may aid initial "collaboration between supply chain members [and] can become a key mechanism to reduce conflicts and foster teamwork, taken to extremes it can also inhibit partnering companies' capabilities to effectively adapt to changing market needs" (Villena, Revilla, \& Choi, 2011, p. 571), leading to failure to cocreate value (Chowdhury, Gruber, \& Zolkiewski, 2016). Excessive experimentation may create competing innovations (Morgan, Anokhin, Kretinin, \& Frishammar, 2015), negatively impacting selling firm ability to successfully innovate, potentially leading to either undifferentiated or overly radical products that customers do not understand. It also depletes resources negatively and impacts small supplier ability to undertake future market development (Morgan et al., 2015).

Because effectuation by small suppliers can also lead to sub-optimal products (in the sense of customer requirements), there is also potential to detrimentally affect the KAM relationship once entered into, particularly where NPD is directed by the larger firm customer. For example, while prior studies identified the usefulness of effectuation when undertaking NPD (Ortega et al., 2017) in promoting NPD speed, it may also negatively impact NPD quality (Wu et al., 2020). Therefore consideration, toward the impact of failed NPD processes on a KAM relationship and interaction between both selling and buying firms and their wider network (Hakansson et al., 2009; Håkansson \& Snehota, 2006) is needed. This paper addresses this gap. 
KAM is a dyadic relationship in which buyer and supplier invest significant resource with the intention of developing long term, mutually beneficial, trading relationships (Davies \& Ryals, 2014). To achieve success and avoid sales failure, asymmetrical outcomes (Chowdhury et al., 2016), perceived unfairness (Abosag, Yen, \& Barnes, 2016) or conflicts of interest (Chung, Wang, Huang, \& Yang, 2016), both parties need to identify opportunities offering genuine mutual benefit and commit resources. They should also accept that KAM relationships may include risks which, to overcome, require trust be developed (Davies \& Ryals, 2014; Grandinetti, 2017; Heidenreich, Wittkowski, Handrich, \& Falk, 2015).

The dark side of KAM relationships may include relationship imbalance with inappropriate actions by either or both parties (Fang, Chang, \& Peng, 2011) and with hostility, distortion, distrust and withholding information (Abosag et al., 2016; Grandinetti, 2017), relationship neglect, complacency and loss of objectivity (Frow, Payne, Wilkinson, \& Young, 2011). This will create negative attitudes toward the relationship that may create uncertainty and potentially lead to conflict (Abosag et al., 2016). In addition, trust and reciprocity may impact decision-making processes, creating unwelcome obligations (Skinner, Dietz, \& Weibel, 2014), which when applied to NPD could result in continuation of a project despite a marginal business case.

\section{Theoretical Development: identifying the antecedents of the dark side}

Hitherto the study of KAM relationships has primarily focused upon those between large customers, resource requirements assumed to be a barrier to small suppliers entering into such relationships (Ivens \& Pardo, 2016). However, while a small supplier may lack resources (McGowan, 2018), entering into a KAM relationship may be made possible through effectuation (McGowan, 2020b). Effectuation theory contrasts with causal logic (which includes goal setting, prediction and planning) because it starts by considering 
available means and then follows an emergent process through which goals develop (Sarasvathy, 2009).

\section{$2.1 \mathrm{KAM}$ resources}

For KAM relationships to be successful, both sides of the buyer-supplier dyad need to commit resources (Davies \& Ryals, 2014). Therefore, it is imperative that appropriate resources, which may include those beyond original contractual terms (Meehan \& Wright, 2011), are available and applied as required (Cambra-Fierro \& Polo-Redondo, 2009; Morrissey \& Pittaway, 2004, 2006). However, differing priorities (Meehan \& Wright, 2011) and lack of flexibility (Fang et al., 2011) may lead to such resources being unavailable.

From a supplier's perspective, resources may include management time to identify KAM opportunities and create a KAM culture; salespeople to build and sustain the relationship, products and services; and resources and investment to customise or adapt, then deliver the solution the buyer requires (Davies \& Ryals, 2014). The adaptability demonstrated by the supplier and their organisation also impacts on buyer perception of the partnership toward a mutually beneficial solution (Friend et al., 2014; Weitz et al., 1986).

From a buyer's perspective, the objective of the relationship is to provide a purchasable solution that adds capability and/or value to the offer the buying firm makes to its own customers (Hakansson et al., 2009). However, due to resource restrictions (Ellegaard, 2006), small suppliers may be unable to provide everything required by a large KAM buyer. Such failure to deliver can be conceptualised as breach of trust (Dasanayaka, Al Serhan, Glambosky, \& Gleason, 2020; Mungra \& Yadav Prabhat, 2019). While clear that relevant resources must be available to avoid this failure, location and ownership of these resources may not be important to the relationship, as long as they are readily available when needed (Hakansson et al., 2009). 
Prior literature does not look at implications of effectuation for small suppliers in KAM relationships, a dearth of empirical work on small firms generally in this area. Yet, effectuation appears to offer a way to overcome small supplier resource restriction. Application of internal and external resources to adapt or customise products or services and/or create new versions or new products, plus any process or new knowledge that may be developed, can themselves become new resources potentially exploitable both within and outside the KAM relationship (Sarasvathy, 2009). Causal logic suggests products/services are developed and targeted toward needs of clearly identified market segments (Terho, Eggert, Haas, \& Ulaga, 2015). In contrast, effectuation suggests once a product/service has been produced, the small supplier would endeavour to exploit it by identifying additional customers to whom it could be successfully sold (Sarasvathy, 2009). Consequently, use of effectuation may provide a way for small suppliers to identify resources needed for a KAM relationship, leading to:

Proposition 1: Effectuation enables a small supplier to overcome resource restriction and therefore enter into a KAM relationship.

\subsection{KAM-related NPD}

Continued use of effectuation may, however, reduce small supplier ability to successfully manage a KAM relationship long term, particularly where it leads to failure to meet KAM partner expectations, breach of trust, and relationship breakdown (Cambra-Fierro \& Polo-Redondo, 2009; Dasanayaka et al., 2020; Morrissey \& Pittaway, 2004, 2006; Mungra \& Yadav Prabhat, 2019). The literature of sales and new product development links customer needs and products/services that should be developed to meet them (Cooper, 2018; Ortega et al., 2017; Sarasvathy, 2009). Sales literature posits that salespeople use questioning techniques to identify what a customer may wish to purchase and they then aim to find 
solutions meeting those needs (Weitz et al., 1986). Within a causal KAM relationship, this may extend to produce a co-created solution from understanding the market, and customer current and anticipated needs (Cooper, 2018; Webb, Ireland, Hitt, Kistruck, \& Tihanyi, 2011). Causal KAM can therefore be considered an ends-based relationship in which resources are identified to meet defined needs (McKelvie, Chandler, DeTienne, \& Johansson, 2019).

The use of effectuation promotes use of market scanning to identify technological, environmental or regulatory changes impacting the landscape (Webb et al., 2011). What is known by the small supplier, plus their network, are then used to identify more creative and less resource intensive opportunities (Sarasvathy, 2009; Webb et al., 2011). This suggests a KAM relationship is entered into between self-selecting partners co-creating solutions based upon the sum of their available means (McKelvie et al., 2019). Once identified, small flexible experiments use readily available resources, both internally and accessed through partners, to uncover new products/solutions taken to market quickly to test and iterate based upon customer feedback (Sarasvathy, 2009; Webb et al., 2011).

Using the effectuation principle of affordable loss, it may be possible to reduce potential losses to acceptable levels to the small supplier (Dew et al., 2009; Roach et al., 2016; Sarasvathy, 2009; Webb et al., 2011). This suggests the process used by small suppliers to create customised, adapted or new products may differ to those applied by large firms (Berends, Jelinek, Reymen, \& Stultiens, 2014; Cooper, 2018; Ortega et al., 2017; Webb et al., 2011).

While well documented in the literature (Cooper, 2018), little attention has been applied to consideration of the outcome if required resources are unavailable, particularly for a small resource limited supplier in a KAM relationship with a larger customer. In this case, 
the larger firm may require resources beyond the capability of the small supplier. This then requires a more effectual approach be taken (Berends et al., 2014; Ortega et al., 2017; Webb et al., 2011).

Effectuation provides a lens through which decisions can be made under uncertainty (Sarasvathy, 2009). This suggests application of effectuation to NPD is likely to positively impact the outcome of NPD (Berends et al., 2014; Ortega et al., 2017) in volume and speed. It may, however, negatively affect the degree to which such NPD produces products matching customer requirements (Ellegaard, 2006; Friend et al., 2014). Lack of resources may also impact small supplier ability to engage in radical innovation, restricting it to projects delivering incremental advances (Woschke, Haase, \& Kratzer, 2017). In addition, resource restriction may further negatively impact development of successful new products because of "lack of market information, failing to listen to the customer, poor up-front predevelopment homework, unstable product definition, poor quality of execution and poorly structured, ineffectual project teams" (Cooper \& Edgett, 2003, p. 48), leading to:

Proposition 2: In NPD relationships within a KAM scenario, the use of effectuation is associated with the creation of new products by resource constrained suppliers. This in turn leads to the development of sub-optimal solutions that risk rejection by the customer.

\subsection{Impact of sub-optimal NPD on buyer-supplier relationships}

Should a co-creation project deliver significantly lower returns than expected, or fail completely, this failure can promote feelings of embarrassment or guilt for either party (McGowan 2020a). Justice theory suggests, in buyer-supplier relationships, fairness is measured by process, quality of interpersonal relationships and mutual respect, and outcomes (Liu, Huang, Luo, \& Zhao, 2012) because failure to deal fairly may promote sales failure (Johnson, Friend, \& Malshe, 2016). Therefore, mutual commitment of resources to a KAM 
relationship carries significant risk and requires mutual trust to avoid failure (Davies \& Ryals, 2014; Friend et al., 2014).

From supplier perspectives, risks include KAM relationships taking longer and being more expensive to deliver results than anticipated (Cuevas, Julkunen, \& Gabrielsson, 2015; Davies \& Ryals, 2014). KAM accounts also tend to be expensive to service and, This suggests KAM relationships carry greater risk for supplier than buyer, mitigated through relationships (Chicksand, 2015), opportunism borne of buyer-supplier power differentials potentially situational (Chicksand, 2015; Hingley, 2005).

In the UK food industry, for example, power is usually vested in a small number of large, market-dominating, retailers (Hingley, 2005), gate-keeping the market by controlling product availability and exposure, for which suppliers may have to provide discounts, promotions, exclusivity, and very high service levels to get their product stocked and sold (Hingley, 2005). The formation of a KAM relationship may provide some form of protection against this opportunism (Chicksand, 2015; Hingley, 2005). To avoid relationship failure and enable commitment to the relationship, mutual trust must be developed and maintained so both parties are clear about the scope and purpose of the KAM relationship, including commitments made and mutual objectives set (Dasanayaka et al., 2020; Davies \& Ryals, 2014; Grandinetti, 2017; Heidenreich et al., 2015; Mungra \& Yadav Prabhat, 2019).

Trust therefore appears to be a prerequisite of relationship commitment, offering one way to potentially mitigate KAM relationship risks (Davies \& Ryals, 2014; Grandinetti, 2017; Heidenreich et al., 2015). Trustworthiness in a KAM situation may be determined as fair dealing (Liu et al., 2012), openly sharing information, not withholding material facts (Grandinetti, 2017), being relationship orientated and acting in each other's best interests (Friend et al., 2014; Guenzi, 2003; Guenzi, De Luca, \& Spiro, 2016; Terho et al., 2015). If 
either supplier or buyer abuses power and/or engages in opportunistic behaviour, this may constitute a breach of trust (Grandinetti, 2017). Trust may also be conceptualised as confidence (Ellegaard, 2009), developed through shared social experience, ethical alignment and mutual respect (Morrissey \& Pittaway, 2004). When a KAM buyer considers trust in relationship to a new supplier, they may relate to the supplier's reputation and brand. As the supplier becomes more established, trust may take become their ability to deliver on their promises (Cambra-Fierro \& Polo-Redondo, 2009; Morrissey \& Pittaway, 2004, 2006; Mungra \& Yadav Prabhat, 2019).

Conversely, trust may be considered broken when co-created goods or services fail to live up to quality expectations (Mungra \& Yadav Prabhat, 2019), deliveries are missed, or there is a breach of any other promise made by the supplier or buyer (Cambra-Fierro \& PoloRedondo, 2009; Morrissey \& Pittaway, 2004, 2006). The most significant breaches of trust can impact the ability of the KAM buyer's firm to deliver on its promises to customers, leading to breakdown of the KAM relationship (Ellegaard, 2006). The need for products/services that live up to the buyer's and their customer's expectations (Friend et al., 2014), and need for both parties to be fair and trustworthily, suggests that processes are needed to control risk and ensure trust (Arli, Bauer, \& Palmatier, 2018; Davies \& Ryals, 2014; Friend et al., 2014; Hakansson et al., 2009; Webb et al., 2011).

Large KAM customers tend to adopt causal approaches to predict, plan, control and avoid surprises (Ivens \& Pardo, 2007). In contrast, effectuation suggests use of affordable loss to manage risk (Dew et al., 2009; Sarasvathy, 2009). Constraining investment in the KAM relationship to one that can be afforded, the small supplier is able to take on risks associated with KAM relationship and keep them in check during relationship. Furthermore, effectuation can actually promote leveraging surprises, creating new opportunities (Dew et al., 2009; Sarasvathy, 2009). Leveraging surprises may lead to the customisation or adaption 
of existing products for exploitation within the KAM relationship. However, if the large firm KAM buyer is using causal logic to predict, plan, control and avoid surprises (Ivens \& Pardo, 2007), but the small KAM supplier is utilising effectuation (Dew et al., 2009; Sarasvathy, 2009), there may be a miss-match of decision-making logic.

Hitherto, the impact of such miss-match of effectuation and causal logic within buyersupplier relationships appears not to have been fully investigated, even though it can result in conflict and potentially lead to KAM relationship breakdown, leading to:

Proposition 3: The predilection of a small supplier adopting effectuation to sell what can be developed using available resources instead of locating the resources required to meet identified market needs, in the longer term negatively affects KAM success.

\section{Method}

An exploratory longitudinal case study approach was adopted (Eisenhardt, 1989; McKelvie et al., 2019; Yin, 2009) that examined a single small supplier operating in the snack foods sector of the UK foods industry. The company was chosen because, in respect of their NPD activities it appeared to use effectuation through experimentation with flexibility of process and outcome, and management of loss potential to that which is affordable (Wu et al., 2020). This behaviour was evident both before and after a KAM relationship was established. This study follows the period in which the small supplier entered into a KAM relationship with a major UK retailer (here forward referred to as KAM partner). It focused on investigating the decision-making of the small supplier within three NPD projects subsequent to establishing this relationship, and also their implications on the relationship with the KAM partner and another key established retail customer (here forward referred to as Retailer B). 
During the period of the study, the small supplier grew in terms of turnover and employees (FTE) by approximately $25 \%$. While the UK registered company initially employed 16 individuals, this grew to 21 individuals. A notable proportion of sales growth resulted from entering into the KAM relationship reported in this paper. However, as the relationship faltered, turnover and full time equivalent (FTE) staff fell back to pre-KAM levels, the business subsequently failing and entering into administration.

The rationale for selection of a longitudinal case study methodology was three-fold. First, McKelvie et al. (2019) argued the longitudinal case study approach is best suited for studying effectuation. Second, case studies are well suited to study of poorly understood phenomena because they use intensive analysis to identify issues and generate insights (Eisenhardt, 1989; Eisenhardt \& Graebner, 2007), and are able to provide rich, detailed, understanding enabling researchers to identify new theoretical relationships (Eisenhardt, 1989). Third, case studies are well suited to understanding problems consisting of multiple and complex elements (Dodgson et al., 2008), uncovering how events evolve over time (Langley, 1999). The study of a single small suppler also enabled understanding of the dynamics present in a particular setting, providing rich insights considered appropriate for theoretical generalisation (Eisenhardt, 1989; Flyvbjerg, 2006; Yin, 1994). This approach is particularly well suited to confirm or challenge theory, represent a unique or extreme case, and illustrate interesting phenomena that can provide important lessons (Sigglekow, 2007; Yin, 1994). By adopting a longitudinal case study approach, the small supplier was studied through 3 years of operation from 2015 to 2018. This, longitudinal, research avoids limitations of studying cases on the basis of retrospective reports (Runyan, 1982), methods applied responding to McKelvie et al's. (2019) call for more longitudinal case study research to understand how effectuation works in real time, as well as understanding antecedents and outcomes of use of effectuation. 
Analysis focuses on four embedded cases of new product development projects, hereafter called Pre-KAM, Case A, Case B and Case C (e.g. Yin, 2009; Eisenhardt, 1989). Each project followed a purposive sampling strategy, being information rich for the phenomenon of interest (Patton, 2002; Creswell and Plano Clark, 2011). Case A presents the first post-KAM brief presented to the small supplier by the KAM partner, hence considered of critical importance. The second case presented the small supplier with an opportunity to significantly increase sales through having its product stocked in prime shelf position, near checkouts within the KAM partner's stores. The final case concerned replacement of a previously unsuccessful product and illustrates how the small supplier's prior failures (Cases A and B) impacted on this product's relative success. While perceived limits of this research design are acknowledged, it would appear well suited to providing new insights within this area of underdeveloped theory, and can also achieve analytical generalisation (Eisenhardt, 1989; Yin, 1994).

\subsection{Case study data collection and analysis}

The scope of data collection included the small supplier, the KAM partner (supermarket retailer), the company's second main retail customer (Retailer B, EU-wide firm), and two independent retailers (Retailers C and D). It was necessary to study each actor within the supply chain because it allowed more complete understanding of the research problem. Figure 1 shows the relationships between the firms discussed in this case study. 


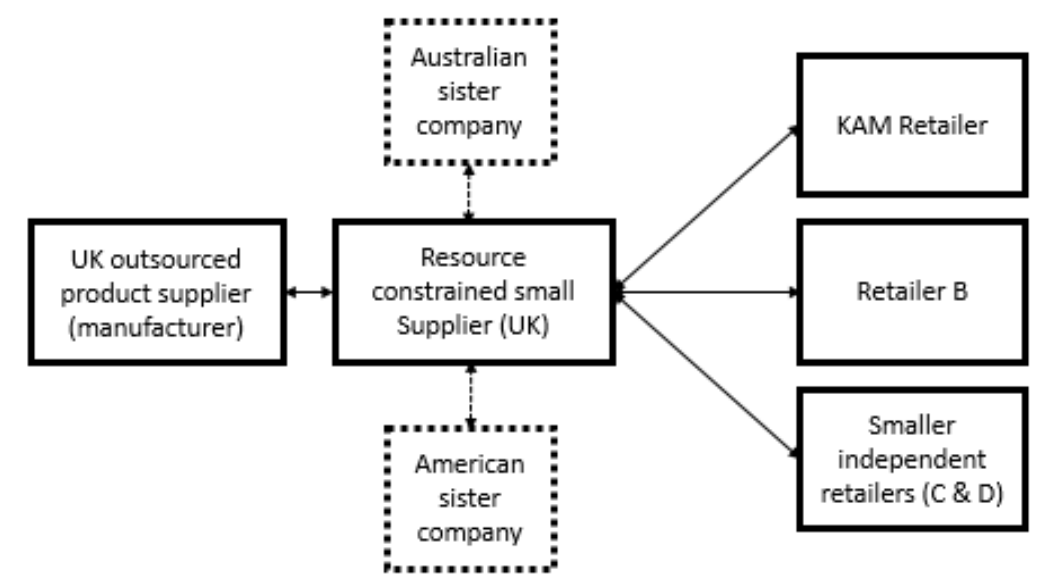

Figure 1: Relationships between firms

Data collection followed the guidelines given by Yin (1994), and Miles and Huberman (1994). Multiple sources of data were used to ensure triangulation (Eisenhardt, 1989; Yin, 1994). The main data collection method is interviews, 66 being conducted over the period of study. Within the company, interviews were conducted with senior management, other key personnel responsible for marketing, account management and product development. Additional interviews were also undertaken within each retailer. Interviews were undertaken at the interviewees' place of work. Data was also collected through attendance at monthly internal meetings between marketing, new product development and sales teams (36 hours); attendance at new product development and sales meetings with retailers (6.5 hours); and presence at conference calls with Australian and American sister business units (SBUs) (3 hours). One member of the research team was also embedded within the organisation for two and a half years working alongside the senior management team. While this individual was closely involved in the projects described in the sections that follow, which further contributed to the detailed insights gathered, they did not have responsibility for or influence the decision-making processes described. 
Initial interviews were conducted using a case study protocol (Yin, 2009). This consisted of set questions tailored to each interview, departure from the structure permitted to allow new points and pertinent points to be explored. For subsequent interviews, questions were developed and elaborated as appropriate to explore pertinent issues and understand new facets of embedded cases as they emerged (Nag, Hambrick, \& Chen, 2007). Interviews typically lasted between one and two hours, and were recorded and transcribed. Notes were also taken during meetings. Interviewees are detailed in Appendix A. Data analysis initially focused on individual cases. Interview transcriptions, were repeatedly reviewed to achieve familiarisation. Transcripts were analysed and examined to categorise, tabulate and recombine evidence, initial propositions used as reference for analysis (e.g. Piekkari, Plakoyiannaki, \& Welch, 2010; Yin, 1994). Utilising the propositions, pattern matching methods were used (Yin, 1994). Each embedded case was analysed by interpreting and comparing the empirical pattern to a predicted pattern. This process was first conduced within each case and then through cross-case analysis. Matching patterns reinforces internal validity. Subsequently, explanation building was used to enhance analytical generalisation (Yin, 1994), evidence interactively examined and each proposition reviewed. Analytical tables ensured a chain of evidence. The emphasis of analysis was understanding the effectuation occurring within each project and how this logic impacted on subsequent projects. Following Kester, Griffin, Hultink, and Lauche (2011), recently highlighted for best practice (Goffin, Åhlström, Bianchi, \& Richtnér, 2019), a summary of analysis and contributions of this study alongside supporting evidence is presented within Table 2.

\section{Results}

The case firm was a UK small supplier with sister companies in the United States and Australia. Each business operated in relative isolation, with separate chief executive officers, although firms did share board members and the UK business imported its main product line 
from the American sister company's outsourced manufacturing partner. Since launching in the UK in 2008, the small supplier operated in the healthy snack foods category of the packaged goods sector. Its products competed in the 'healthy', 'free from', and 'vegan' market sectors. Almost uniquely within the sector, the product was not heated, thus retaining more naturally occurring vitamins and minerals.

\subsection{Pre KAM case}

Entering the UK market the small supplier's main product line had been imported from an outsourced manufacturer contracted by its American sister company. This consisted of five flavours whey protein enriched snacks with nuts and seeds, nut and seed pastes, and fruit extracts, and three flavours enriched with vegan protein. Recognising the potential to secure accounts with top UK retailers, the firm "recognised a need to establish UK manufacturing in order to ensure a fresher supply of products and the potential for greater volumes" [I1].

This process culminated in iterative production scale-up tests and kitchen tests leading to a final recipe. The product was launched in the first quarter of 2017. However, further iterations were required to two flavours because of inconsistencies between the UK and American products. Having begun production in the final quarter of 2016, the firm initially supplied retailers with both the UK and American versions. The firm slowly scaled down American imports over the following months to minimise risk during changeover.

Although this small supplier had attempted to enter into a top UK supermarket retailer a number of times since inception, it had been unsuccessful because of insufficient perceived demand and potential for sales growth. However, late in 2015, with growing sales in 'healthy' and 'free from' categories, following approximately five months of negotiation, the small supplier secured an account with a leading retailer. The new account was internally considered to be the "most significant client to date, and the greatest opportunity for our 
sales growth since entering the UK... whilst we are pursuing the other top retailers, we think this firm provides us with the greatest opportunity for sales growth and customer reach" [I4].

Hence the small supplier dedicated an account manager to the retailer (KAM partner), who closely monitored sales and further developed the subsequent relationship. The small supplier's detailed long-term plans to establish UK manufacturing (Project Case A) formed " a key piece in securing the retailer and providing additional security on supply, whilst providing us with the potential to maintain margins despite their requirements to participate in regular promotions" [I5].

Ultimately, the small supplier's investments alongside growth in sales in its core product line resulted in it being provided with three key opportunities to develop new products for the KAM partner (Cases A-C). An overview of the cases is presented in Table 1.

Table 1: Overview of Case Projects

\begin{tabular}{|c|c|c|c|c|}
\hline & Pre-KAM Case & $\begin{array}{l}\text { Case A: Vegan } \\
\text { product }\end{array}$ & $\begin{array}{l}\text { Case B: } 100 \\
\text { calorie snack }\end{array}$ & $\begin{array}{l}\text { Case C: Bite size } \\
\text { relaunch }\end{array}$ \\
\hline $\begin{array}{l}\text { Ultimate market } \\
\text { launch date, by } \\
\text { quarterly period }\end{array}$ & First Quarter 2017 & Second Quarter 2017 & First Quarter 2018 & Second Quarter 2018 \\
\hline Project initiator & $\begin{array}{l}\text { Opportunity to enter } \\
\text { into KAM } \\
\text { relationship with } \\
\text { Top } 3 \text { UK retailer }\end{array}$ & $\begin{array}{l}\text { Request from KAM } \\
\text { partner to develop a } \\
\text { vegan biscuit based } \\
\text { on market data }\end{array}$ & $\begin{array}{l}\text { Request from KAM } \\
\text { partner to develop a } \\
\text { smaller } 100 \text { calorie } \\
\text { version of } \\
\text { established product } \\
\text { line of individually } \\
\text { packed health } \\
\text { product }\end{array}$ & $\begin{array}{l}\text { Rejuvenation and } \\
\text { relaunch of } \\
\text { unsuccessful bite } \\
\text { size product to meet } \\
\text { established market } \\
\text { demand }\end{array}$ \\
\hline NPD Logic & $\begin{array}{l}\text { Effectuation: } \\
\text { adopted to utilise } \\
\text { resources of } \\
\text { outsourced } \\
\text { manufacturer and } \\
\text { minimise } \\
\text { investments in } \\
\text { development of } \\
\text { internal resources. } \\
\text { Project emphasis } \\
\text { recipe replication. }\end{array}$ & $\begin{array}{l}\text { Effectuation: to } \\
\text { utilise American } \\
\text { sister company's } \\
\text { NPD alongside in an } \\
\text { attempt to address } \\
\text { brief whilst } \\
\text { minimising } \\
\text { investment and } \\
\text { development time. } \\
\text { Emphasis largely on } \\
\text { existing ingredients } \\
\text { with added spices to } \\
\text { mask inherent } \\
\text { flavour and spherical } \\
\text { product shape. }\end{array}$ & $\begin{array}{l}\text { Effectuation: to } \\
\text { repackage an } \\
\text { alternative less- } \\
\text { established product } \\
\text { consisting of } \\
\text { multiple small pieces } \\
\text { in order to reach a } \\
\text { 100-calorie target, as } \\
\text { opposed to investing } \\
\text { in redevelopment } \\
\text { and new production } \\
\text { for smaller version } \\
\text { of established } \\
\text { product }\end{array}$ & $\begin{array}{l}\text { Causal logic: } \\
\text { adopted to develop a } \\
\text { new bite sized } \\
\text { product using new } \\
\text { ingredients to } \\
\text { develop an } \\
\text { appropriate product } \\
\text { that would meet } \\
\text { market demand }\end{array}$ \\
\hline
\end{tabular}




\begin{tabular}{|l|l|l|l|l|}
\hline $\begin{array}{l}\text { Partners involved in } \\
\text { NPD project }\end{array}$ & $\begin{array}{l}\text { American sister } \\
\text { company and } \\
\text { outsourced UK } \\
\text { manufacturer }\end{array}$ & $\begin{array}{l}\text { American sister } \\
\text { company }\end{array}$ & $\begin{array}{l}\text { Product } \\
\text { manufacturer }\end{array}$ & $\begin{array}{l}\text { Internal } \\
\text { development, with } \\
\text { ingredients suppliers }\end{array}$ \\
\hline $\begin{array}{l}\text { Acceptance/rejection } \\
\text { by KAM partner } \\
\text { and retailers }\end{array}$ & Accepted & $\begin{array}{l}\text { Rejected by KAM } \\
\text { partner } \\
\text { Limited retail } \\
\text { success }\end{array}$ & $\begin{array}{l}\text { Rejected by KAM } \\
\text { partner } \\
\text { Discontinued shortly } \\
\text { after launch }\end{array}$ & $\begin{array}{l}\text { Rejected by KAM } \\
\text { partner } \\
\text { Limited retail } \\
\text { success }\end{array}$ \\
\hline $\begin{array}{l}\text { Relative Product } \\
\text { Success }\end{array}$ & $\begin{array}{l}\text { Project enabled } \\
\text { successful entry into } \\
\text { KAM retailer, } \\
\text { alongside other } \\
\text { retailers. }\end{array}$ & $\begin{array}{l}\text { Following rejection } \\
\text { by KAM partner, } \\
\text { limited success in } \\
\text { other established } \\
\text { health food retailers. }\end{array}$ & $\begin{array}{l}\text { Following rejection } \\
\text { by KAM partner and } \\
\text { Retailer B, limited } \\
\text { success in } \\
\text { independent stores } \\
\text { (including Retailers } \\
\text { C and D) and } \\
\text { subsequently } \\
\text { discontinued. }\end{array}$ & $\begin{array}{l}\text { Retailers willingness } \\
\text { to stock product, and } \\
\text { thus sales, impaired } \\
\text { by failure of prior } \\
\text { products (both } \\
\text { unsuccessful prior } \\
\text { version and Cases A } \\
\text { and B). }\end{array}$ \\
\hline
\end{tabular}

The following section details analysis of the initial development project to move manufacturing to the UK, key to entering into a KAM relationship, and the three new product development projects that subsequently occurred.

\subsection{Case A: Vegan Product}

In Q4 2016, a top four UK retailer approached the account manager to develop a new product exclusively for their stores. Having secured the retailer as a customer less than six months prior, this was seen as a "significant opportunity... [and]... a chance to develop our relationship with what may become our largest account" [I2]. Informed by a recent market report highlighting growing demand for savoury biscuits and decline in sales of sweet biscuits, the retailer identified an opportunity to supply a high-protein natural vegan savoury biscuit. The retailer briefed the small supplier.

At this point, the brand owner still imported most of its products, only just beginning UK manufacturing. Hence, it went back to its US manufacturer who produced the current vegan products: "it would be far quicker and save significant costs to develop it based on our current vegan product, increasing the protein content and moving from sweeter ingredients to 
savoury ingredients to flavour it" [I4]. Product development resources were limited, due to recent investments in marketing and join manufacturing investments, and failure costly.

After several rounds of internal development, five new flavours were produced: "with the characteristics of our ingredients we found that it was most appropriate to use quite strong flavours" [I8]. The account team held a meeting with the retailer who rejected the proposed product, seen as poorly fitting the original requirements - it was not a biscuit and the flavours were too spicy and strong.

With five flavours already developed, the brand owner decided to repurpose. Updating the range was long overdue, customers and retailers having requested changes. The company had been delaying redevelopment due to investment requirements, hence the new products could address these issues.

Existing health food retailers were approached and offered the product as "an exclusive product to our long-standing customers" [I2]. The existing sweet vegan range would be phased out. The product was launched early in the second quarter of 2017, accepted by several retailers shortly after this. Sales proved disappointing. The spicy product was too dissimilar to qualities that the customers had bought into, which also resulted in complaints. While recognising a nascent market, the new range failed to provide growth for brand or retailers. Four months post launch one large retailer reduced the number of flavours stocked due to poor sales, while others only stocked a smaller number of products and some moved to a competitor's products. Having invested their limited resources into this project, the firm was unable to invest in replacing the products.

\subsection{Case B: 100 calorie snack}

A meeting with the Key Account retailer revealed that to be labelled a single serving, a snack product would need to be less than one hundred calories. Most of the company's 
existing products would be labelled as 1.5 servings. The retailer was interested in stocking more of the firm's main product line near its checkout counters but to do this they requested the size of the product be reduced to lower the calories.

Full compliance would require significant resource investment to manufacture two different ball sizes and packs. The firm was reluctant due to NPD investments, increased production complexity and development time. The retailer was also undertaking a change to store merchandising to promote healthy product and the team were concerned that: "we felt there was a window and we might not have enough time to respond" [I6]. It would be more feasible, faster and cheaper to take a small bite size product recently introduced by one of its overseas SBUs (but new to the UK market) and pack them into a smaller flow wrap containing three bites, The effectuated solution would achieve the nutritional objective. A graphic designer was enlisted to create a pack for the UK market and a packaging manufacturer instructed to create a smaller elongated tube-shaped flow wrap.

Following a short development period, the small supplier took the product to the retailer late in the third quarter of 2017 but "they were not interested in stocking this solution" [I6]. The retailer had intended to use the company's most recognised and established product, on which the Key Account relationship had been established.

Subsequently, the company again decided to launch the product at small scale with its traditional retailers: "we had taken a decision to import some batches, so it made sense to try the product in the market. It did not, however, prove sufficiently successful: it was higher in sugars than our established product and this isn't congruent with our [UK] brand" [I3]. The traditional retailers also expressed the view that a smaller product would be better packed more like a small bag of peanuts to attract attention. The product was subsequently discontinued seven months after launch. 


\subsection{Case C: Bite size relaunch}

Following requests from retailers and consumers, in the second quarter of 2016 the brand had initially launched a bite size product in conjunction with a small UK manufacturer: "they had production capacity and were able to develop something for us to deliver to the market in just a few months... their costs were minimal and it enabled us to deliver a UK sourced product" [I1]. However, over 18 months, the product had achieved relatively poor sales and been delisted by several retailers. This ultimately led to the decision to discontinue it, due to a poor taste, low protein content, and short shelf life, which had also resulted in customer complaints. The firm decided to revisit the opportunity and, having recently built a small development team through a part government funded project, this was seen as a key project for future growth: "we have known for years there is an underlying demand" [I2].

After a long development project, in the fourth quarter of 2017, the firm was ready to launch: "we knew it was a stronger offering ... it was high in protein, the taste profile had been well received and it had a relatively low sugar content" [I4]. Several new ingredients had been introduced to develop an offering appropriate to market requirements.

When the firm approached its Key Account and other retailers, their interest in stocking the new product was limited: “... initially they said they would revisit the decision several months later and when we finally got them to stock it they were only interested in two SKU's... they stocked it on a very limited basis" [I7]. When they went back to their longstanding largest traditional client, they only agreed to provide limited shelf space: "when we launched the original they had been very keen to stock it, and we all knew there was a demand for this kind of offering... but this time they were reluctant to provide us with an opportunity to prove the product's potential" [I9]. 
The company also struggled to get its new bite size product into several other traditional retailers because, after removing the initial bites, they had provided that space to new entrants with similar but superior products meeting latent need. This was a significant blow because the product had been the first major project for the development team, and had been developed casually rather than effectually.

\section{Discussion and theoretical contribution}

Table 2 summarises analysis of the cases. In the first and second rows the three propositions are presented within the literature review, alongside a fourth proposition developed from findings. The following two rows (3 and 4) summarise the evidence from each case pertinent to each proposition, followed by proof quotes offering supporting evidence. Subsequently the table links this to the findings of prior studies (row 5) and then identifies how findings are differentiated from prior studies (row 6). In doing so, the table identifies the new understanding provided by our study into the dark side of effectuation within the context of a small supplier's relationship with a KAM partner. The following section discusses and summarises this analysis for the three propositions. In addition, analysis suggests that use of effectuation, when engaged in KAM-related NPD, may lead to development of a dark side within the buyer-supplier relationship, created through misrepresentation of capability, leading to development of sub-optimal products perceived by the KAM customer as a breach of trust (Mungra \& Yadav Prabhat, 2019). 
Table 2: Summary of Case Study Analysis with Supporting Evidence and Identification of Contributions

\begin{tabular}{|c|c|c|c|c|}
\hline & $\begin{array}{l}\text { Proposition 1: } \\
\text { KAM entry }\end{array}$ & $\begin{array}{l}\text { Proposition 2: Effectual } \\
\text { NPD }\end{array}$ & $\begin{array}{l}\text { Proposition 3: Effectual } \\
\text { selling }\end{array}$ & $\begin{array}{l}\text { Dark side of } \\
\text { effectuation (P4 new } \\
\text { contribution) }\end{array}$ \\
\hline Proposition & $\begin{array}{l}\text { Effectuation } \\
\text { enables a small } \\
\text { supplier to } \\
\text { overcome } \\
\text { resource } \\
\text { restriction and } \\
\text { therefore enter } \\
\text { into a KAM } \\
\text { relationship. }\end{array}$ & $\begin{array}{l}\text { In NPD relationships } \\
\text { within a KAM scenario, } \\
\text { the use of effectuation } \\
\text { increases the likelihood } \\
\text { of creating of new } \\
\text { products by resource } \\
\text { constrained small } \\
\text { suppliers but also } \\
\text { increases the likelihood } \\
\text { of developing sub- } \\
\text { optimal solutions which } \\
\text { risk rejection by the } \\
\text { customer. }\end{array}$ & $\begin{array}{l}\text { The predilection of a } \\
\text { small supplier adopting } \\
\text { effectuation to sell what } \\
\text { can be developed using } \\
\text { available resources } \\
\text { instead of locating the } \\
\text { resources required to } \\
\text { meet identified market } \\
\text { needs, in the longer term } \\
\text { negatively affects KAM } \\
\text { success. }\end{array}$ & $\begin{array}{l}\text { Use of effectuation by a } \\
\text { small supplier that leads } \\
\text { to the development of } \\
\text { sub-optimal products } \\
\text { may be viewed by } \\
\text { customers as breach of } \\
\text { trust. This in turn holds } \\
\text { the risk of relationship } \\
\text { breakdown. }\end{array}$ \\
\hline $\begin{array}{l}\text { Summary of } \\
\text { supporting case } \\
\text { study evidence }\end{array}$ & $\begin{array}{l}\text { Pre-KAM Case: } \\
\text { The small } \\
\text { supplier leveraged } \\
\text { its sister } \\
\text { company's } \\
\text { product, } \\
\text { outsourcing its } \\
\text { manufacture to a } \\
\text { UK firm, which } \\
\text { enabled it to enter } \\
\text { the supermarket } \\
\text { and subsequently } \\
\text { establish a KAM } \\
\text { relationship. To } \\
\text { develop products, } \\
\text { the small supplier } \\
\text { became more } \\
\text { reliant upon its } \\
\text { suppliers to } \\
\text { undertake NPD } \\
\text { activities. }\end{array}$ & $\begin{array}{l}\text { Case A: Retailer B } \\
\text { (health food retailer) } \\
\text { experienced poor sales } \\
\text { from the new savoury } \\
\text { vegan range, developed } \\
\text { by its American supplier } \\
\text { based on existing } \\
\text { ingredients. This led to } \\
\text { the delisting of several } \\
\text { products within the line, } \\
\text { which were replaced by } \\
\text { other less-established } \\
\text { competing brands. This } \\
\text { retailer complained to the } \\
\text { brand owner that the } \\
\text { product was not fulfilling } \\
\text { the market's needs. } \\
\text { Case B: Retailer B and } \\
\text { independent stores } \\
\text { (Retailers C and D) lack } \\
\text { of interest in the one } \\
\text { hundred calorie snack, } \\
\text { based on a repackaged } \\
\text { version of an existing } \\
\text { product, subsequent to } \\
\text { rejection by the KAM } \\
\text { partner, resulting in the } \\
\text { product being } \\
\text { discontinued. } \\
\text { Case C: The small } \\
\text { supplier struggled to get } \\
\text { its new product adopted } \\
\text { by both the new KAM } \\
\text { partner and Retailer B, } \\
\text { despite the previous } \\
\text { version having been } \\
\text { stocked by the latter. } \\
\text { Disappointing levels of } \\
\text { interest in trailing the }\end{array}$ & $\begin{array}{l}\text { Case C: The KAM } \\
\text { partner was concerned by } \\
\text { the small supplier's prior } \\
\text { sub-optimal and failed } \\
\text { products, which } \\
\text { impacted on the small } \\
\text { supplier's ability to get } \\
\text { their new bite sized } \\
\text { product stocked despite } \\
\text { acknowledgement from } \\
\text { the retailer of the } \\
\text { potential market and } \\
\text { improved product } \\
\text { characteristics. }\end{array}$ & $\begin{array}{l}\text { Case A: Compromises to } \\
\text { the design were accepted } \\
\text { by the internal } \\
\text { development team, } \\
\text { despite recognition that } \\
\text { this would not fully } \\
\text { address the brief, to } \\
\text { utilise the available } \\
\text { resources. The rationale } \\
\text { for this was to reduce } \\
\text { costs and improve } \\
\text { development speed. The } \\
\text { product evolved from the } \\
\text { small supplier's existing } \\
\text { product line. Hence, it } \\
\text { did not meet the KAM } \\
\text { partner's original brief in } \\
\text { terms of flavours or } \\
\text { shape. Thus, the KAM } \\
\text { partner was unwilling to } \\
\text { stock it. } \\
\text { Case B: The KAM } \\
\text { partner was interested a } \\
\text { smaller version of the } \\
\text { company's established } \\
\text { product. Presenting the } \\
\text { solution of several small } \\
\text { bite sized pieces wrapped } \\
\text { together did not meet this } \\
\text { requirement, and it was } \\
\text { seen to the partner to fail } \\
\text { to capitalise on the } \\
\text { brand's successful } \\
\text { product line within the } \\
\text { potential high-volume } \\
\text { store positioning on } \\
\text { offer. }\end{array}$ \\
\hline
\end{tabular}




\begin{tabular}{|c|c|c|c|c|}
\hline & & $\begin{array}{l}\text { product among smaller } \\
\text { stores were also reported. }\end{array}$ & & \\
\hline Proof quotes & $\begin{array}{l}\text { Pre-KAM: } \\
\text { "Shifting } \\
\text { manufacturing to } \\
\text { the UK, using the } \\
\text { recipes from } \\
\text { America, was a } \\
\text { key step in } \\
\text { enabling the } \\
\text { continued } \\
\text { expansion of our } \\
\text { growth as we } \\
\text { moved into the } \\
\text { larger retailers." } \\
\text { [I1] }\end{array}$ & $\begin{array}{l}\text { Case A: "Whilst the } \\
\text { protein content had been } \\
\text { increased, the taste is not } \\
\text { what the customer is } \\
\text { looking for in this kind } \\
\text { of product. They are } \\
\text { effectively looking for a } \\
\text { healthy sweet snack." } \\
\text { [I8] } \\
\text { Case B: "They believed a } \\
\text { similar product packed in } \\
\text { a rectangular flow wrap, } \\
\text { a bit like a packet of } \\
\text { nuts... would have been } \\
\text { more desirable as a } \\
\text { convenience offering... } \\
\text { It was clear this impacted } \\
\text { on their decision to reject } \\
\text { the product. [discussing } \\
\text { health food retailer]" [I7] } \\
\text { Case C: "The problems } \\
\text { with the prior product } \\
\text { resulted in the retailer } \\
\text { being less willing to } \\
\text { stock it, despite } \\
\text { acknowledging the } \\
\text { improvements." [I4] }\end{array}$ & $\begin{array}{l}\text { Case C: "The buyer } \\
\text { acknowledged that this } \\
\text { seemed like a good } \\
\text { product with a good } \\
\text { market fit. But he was } \\
\text { unwilling to trial it, due } \\
\text { to the problems we had } \\
\text { experienced with the } \\
\text { product it replaced." [I5] }\end{array}$ & $\begin{array}{l}\text { Case A: } \\
\text { "We were told they were } \\
\text { too 'curry like' in the } \\
\text { flavouring and were not } \\
\text { really as biscuit... which } \\
\text { was the original brief... } \\
\text { We had a challenging } \\
\text { meeting and the buyer } \\
\text { questioned our decision } \\
\text { making." [I2] } \\
\text { Case B: "To develop a } \\
\text { [brand name removed] to } \\
\text { the specifications desired } \\
\text { would have created a } \\
\text { need for investments and } \\
\text { complicated the } \\
\text { production process... } \\
\text { that led to our decision to } \\
\text { use the imported [brand } \\
\text { name of product } \\
\text { removed]." [I2] }\end{array}$ \\
\hline $\begin{array}{l}\text { Link to extant } \\
\text { literature }\end{array}$ & $\begin{array}{l}\text { Working in } \\
\text { partnership } \\
\text { provides } \\
\text { opportunities to } \\
\text { share resources, } \\
\text { create new } \\
\text { products and } \\
\text { access new } \\
\text { markets (Ortega } \\
\text { et al., 2017; Wu et } \\
\text { al., 2020) }\end{array}$ & $\begin{array}{l}\text { Effectuation would } \\
\text { suggest that the small } \\
\text { supplier leverage } \\
\text { contingencies } \\
\text { (Sarasvathy, 2009). } \\
\text { Thus, rejection of } \\
\text { product by one customer } \\
\text { is not necessarily a } \\
\text { failure, if leveraged, it } \\
\text { could open up } \\
\text { opportunities to sell into } \\
\text { a new customer base or } \\
\text { market sector (Ortega et } \\
\text { al., 2017). }\end{array}$ & $\begin{array}{l}\text { Only access to resources } \\
\text { is captured by the } \\
\text { existing literature, } \\
\text { whereas location of } \\
\text { resources is considered } \\
\text { to lack significance } \\
\text { (Sarasvathy, 2009). }\end{array}$ & $\begin{array}{l}\text { Effectuation suggests } \\
\text { that loss is constrained to } \\
\text { that which can be } \\
\text { afforded by the small } \\
\text { supplier, this enabling a } \\
\text { risk to be taken (Dew et } \\
\text { al., 2009). } \\
\text { Dark side of relationship } \\
\text { may include } \\
\text { unintentional breaches of } \\
\text { trust (Oliveira \& } \\
\text { Lumineau, 2019). }\end{array}$ \\
\hline $\begin{array}{l}\text { Differentiation } \\
\text { from the } \\
\text { literature }\end{array}$ & $\begin{array}{l}\text { While it is } \\
\text { suggested that } \\
\text { effectuation } \\
\text { enables resource } \\
\text { restrictions by the } \\
\text { small supplier to } \\
\text { be overcome to } \\
\text { enter a KAM } \\
\text { relationship, there } \\
\text { is a lack of } \\
\text { empirical } \\
\text { evidence to } \\
\text { support this. } \\
\text { Within our case } \\
\text { study it was }\end{array}$ & $\begin{array}{l}\text { This study suggests that, } \\
\text { in line with effectuation, } \\
\text { the attempt to recover } \\
\text { resources previously } \\
\text { depleted to produce a } \\
\text { sub-optimal product } \\
\text { through the further } \\
\text { expenditure of additional } \\
\text { resources, can lead to a } \\
\text { tarnished company } \\
\text { reputation for the small } \\
\text { supplier. In turn, this can } \\
\text { further deplete resources. }\end{array}$ & $\begin{array}{l}\text { Our study reveals the } \\
\text { importance of the } \\
\text { location of resources, } \\
\text { which is in contrast to } \\
\text { the existing literature } \\
\text { which states that } \\
\text { providing resources can } \\
\text { be accessed through } \\
\text { personal means they can } \\
\text { be effectively utilised } \\
\text { (Sarasvathy, 2009). } \\
\text { A lack of resource } \\
\text { control, as a result of } \\
\text { manufacturing }\end{array}$ & $\begin{array}{l}\text { The impact of trust and } \\
\text { effectuation has not been } \\
\text { identified previously. } \\
\text { This study suggests that } \\
\text { effectuation, leading to } \\
\text { the development of sub- } \\
\text { optimal products may be } \\
\text { viewed by customers as } \\
\text { breach of trust. This in } \\
\text { turn holds the risk of } \\
\text { relationship breakdown. }\end{array}$ \\
\hline
\end{tabular}




\begin{tabular}{|l|l|l|}
\hline $\begin{array}{l}\text { observed that the } \\
\text { small supplier } \\
\text { was able to utilise } \\
\text { this method for } \\
\text { relationship entry. }\end{array}$ & $\begin{array}{l}\text { outsourcing, contributed } \\
\text { to the acceptance of } \\
\text { compromises by the } \\
\text { effectual-led KAM } \\
\text { partner. In turn, this led } \\
\text { to the development of a } \\
\text { sub-optimal product to } \\
\text { be supplied to the KAM } \\
\text { partner. These findings } \\
\text { identify the need for } \\
\text { users of effectuation to } \\
\text { achieve availability } \\
\text { alongside gaining control } \\
\text { over the key resources } \\
\text { required. }\end{array}$ \\
\hline
\end{tabular}

\subsection{Theoretical contribution: the unintentional dark side of effectuation}

Previous study of KAM relationships has primarily focused upon large firms, given that resource requirements have been assumed to be a barrier to small suppliers entering into such a sales relationship (Ivens \& Pardo, 2016). In contrast, this study specifically focused on what happens when a small resource constrained supplier enters a KAM relationship.

Findings show that use of effectuation has potential to develop a dark side within business-tobusiness buyer-supplier relationships through unintentional breaches of trust by the small supplier (Oliveira \& Lumineau, 2019). It has been possible to develop a conceptual model by using conceptual deduction (Meredith, 1993), synthesising study findings with literature pertaining to KAM, NPD activity and effectuation (Sarasvathy, 2009), presented in Figure 2. This highlights how sales failure can eventuate from effectuation, feeding back negatively into future NPD processes and outcomes (discussed in more detail later on). The following three sections analyse key findings for the three research propositions, followed by discussion of how continued effectuation resulted in a breach of customer trust. This finding forms a key output of the case study findings. 


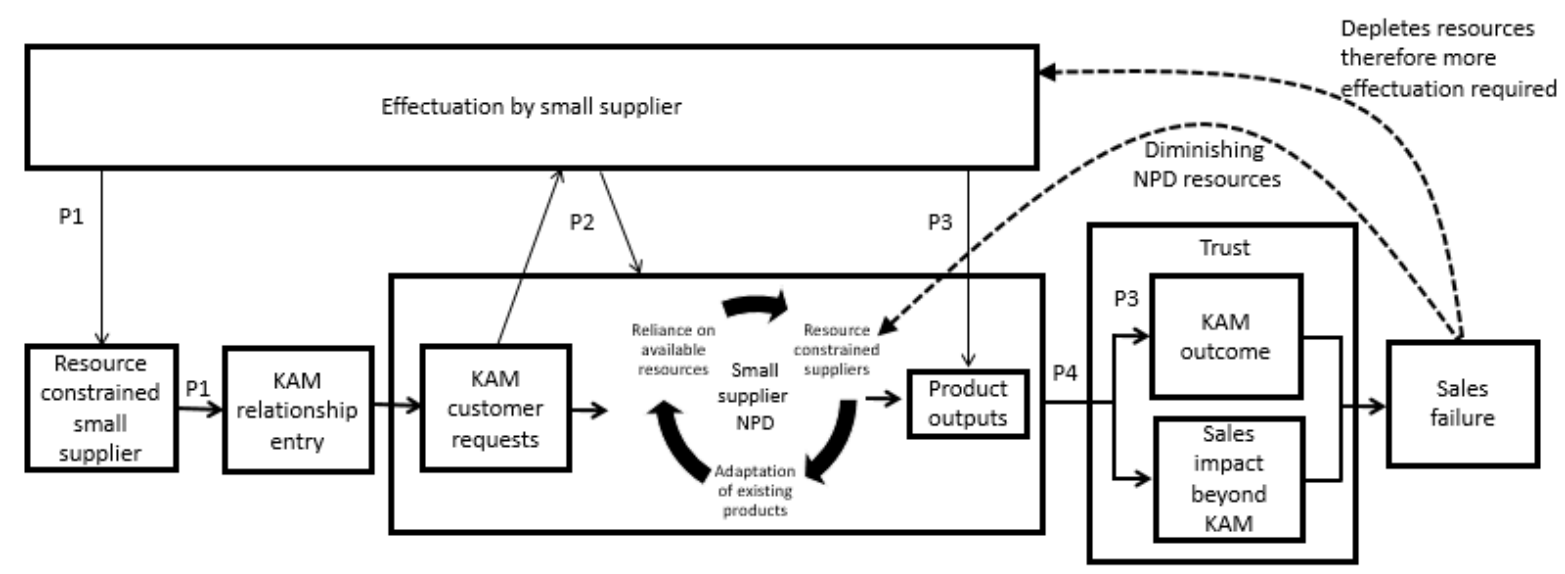

Figure 2: The impact of effectuation on customer trust and relationship outcome.

\subsection{KAM entry}

In the first pre-KAM case, market and product needs were identified by the Key Account. The small supplier leveraged its sister company's product, previously imported from America, and outsourced its manufacture to a UK firm. This enabled the small supplier to enter the KAM partner and subsequently establish a KAM relationship, without making significant investment in new resources or creating new internal capabilities: "Shifting manufacturing to the UK, using the recipes from America, was a key step in enabling the continued expansion of our growth as we moved into the larger retailers.... This was a key step for us" [I2]. To develop products, the small supplier became reliant upon outsourced suppliers, which manufactured the product, for NPD activities, because of limited knowledge of core product and production process. This suggests an effectual process was indeed used by the small supplier to enter into a KAM relationship, using of effectuation to enable involvement in KAM-related NPD (Berends et al., 2014; Ortega et al., 2017; Sarasvathy, 2009), (external) NPD resources accessed through effectuation means (Roach et al., 2016; Sarasvathy, 2009) and risk reduced through affordable loss (Dew et al., 2009). The preceding 
lends support to Proposition 1. The conceptual literature suggested effectuation can be used to overcome resource restrictions to KAM entry, this case study providing empirical evidence of such use by a small supplier.

\subsection{Effectual NPD}

In Cases A and B, the small supplier utilised resources of its outsourced supplier that manufactured the product, and attempted to adapt existing products they produced to meet KAM partner's requirements. The small supplier lacked resources to either internally develop new products using causal logic or outsource development to ensure the KAM partner's requirements were fully met. Consequently, each product was rejected by the KAM partner because they did not meet the requirements placed on the small supplier. Following this rejection, in line with effectuation, the small supplier took the opportunity to recover resources by taking the same products to a different set of customers (Ortega et al., 2017). In

Case A, Retailer B, the health food retailer, experienced poor sales from the new savoury vegan range. This led to delisting several products within the line, replaced by other lessestablished competing brands. Retailer B complained to the brand owner that the product was not fulfilling the market's needs: "Whilst the protein content had been increased, the taste is not what the customer is looking for in this kind of product. They are effectively looking for a healthy sweet snack” [I7]. In case B, other small independent stores were approached but lacked interest in the 100 calorie snack, resulting in the product being discontinued. For example: "They believed a similar product packed in a rectangular flow wrap, a bit like a packet of nuts... would have been more desirable as a convenience offering... It was clear this impacted on their decision to reject the product [discussing health food retailer] " [I2]. Case $\mathrm{C}$ demonstrated wider impact of developing sub-optimal products, beyond a single project. The small supplier struggled to get its new product adopted by both the new KAM partner and Retailer B, even though the previous version had been stocked by the latter. It 
also reported disappointing levels of interest in trailing the product among smaller stores. One interviewee stated: "The problems with the prior product resulted in the retailer being less willing to stock it, despite acknowledging the improvements" [I8]. These findings suggest that, in line with effectuation, attempts to recover resources previously depleted to produce a sub-optimal product through the further expenditure of additional resources may have damaged the small supplier's reputation, further depleting resources. These findings provide support for Proposition 2.

\subsection{Effectual selling to a KAM partner}

Effectual selling is the use of effectuation to access resources needed by a small supplier to meet customer requirements (McGowan, 2020b). Cases A and B revealed the application of effectuation in fact led to development of sub-optimal products. The small supplier focused on redeveloping and adapting existing products instead of investing in creating products that exactly met the requirements of the KAM partner as their customer, resulting in compromises. Their desire to utilise existing resources was prioritised over addressing KAM partner needs. For example, in Case B this precluded investments in new production equipment to create a product that met KAM partner requirements. As the KAM partner had set pre-determined product specifications and quality expectations, offered goods were deemed inappropriate and were rejected. Furthermore, the KAM partner was concerned by the small supplier's prior failed NPD efforts, which had resulted in products not meeting the original brief. This impacted small supplier's ability to get their new product stocked, despite acknowledgement of the potential market. For example, one interviewee discussed the KAM partner's response: “The buyer acknowledged that this seemed like a good product with a good market fit. But he was unwilling to trial it, due to the problems we had experienced with the product it replaced." [I5]. This lends support for Proposition 3 because 
the KAM customer no longer trusted the small supplier to deliver products that would meet their brief (Mungra \& Yadav Prabhat, 2019).

\subsection{Breach of trust}

Findings of this study provide new understanding of the influence of effectuation on trust between small supplier and retailer customers. In respect of Case A, instead of developing a new product that fully met KAM partner requirements, an existing product was adapted to reduce costs. However, in doing so, the KAM partner's original brief in terms of flavours or shape was not met. Hence, the KAM partner was unwilling to stock it: "We were told they were too 'curry like' in the flavouring and were not really a biscuit... which was the original brief." [110]. Case B shows a similar tendency to use effectuation to meet customer requirements (Sarasvathy, 2009). While presenting the solution of several small pieces of a different product wrapped together reduced the investment and development costs, it did not meet the brief. The KAM partner had intended to capitalise on the small supplier's wellknown and established product line with a potential high-volume store positioning on offer: "To develop a [brand name removed] to the specifications desired would have created a need for investments and complicated the production process... that led to our decision to use the imported [brand name removed] " [I1]. The small supplier's unwillingness or inability to invest in a causal NPD process led to development of a sub-optimal product, subsequently rejected by the KAM partner. Case $\mathrm{C}$ details how products $\mathrm{A}$ and $\mathrm{B}$, previously rejected by the KAM partner and subsequently offered for sale to other customers, subsequently affected the small supplier's other relationships. Specifically, the experiences of retailers in relation to Cases A and B developed using effectuation and in Case C contributed to the small supplier struggling to get its new (causally developed) product adopted by KAM partner and established customer (Retailer B). This was despite the previous version having been stocked by Retailer B. It also reported disappointing levels of interest in trialling the product among 
smaller and both independent stores (Retailers C and D). The sales team cited lack of trust as a key factor negatively influencing their ability to get the new product accepted.

This leads to consideration of the efficacy of effectuation. While extant literature provides support for its use by a small supplier within a wide range of activities (Roach et al., 2016; Sarasvathy, 2009), including NPD (Ortega et al., 2017; Wu et al., 2020), it would appear its use can be an antecedent to broken trust between buyer and supplier. While the impact of trust in sales is well understood (Davies \& Ryals, 2014; Grandinetti, 2017), it would appear that the apparent link between use of effectuation and a resultant breakdown of trust within a KAM relationship has not previously been identified.

\section{Conclusions and contributions}

This study responds to McGowan's (2020b) call to investigate the efficacy and limitations of effectuation within buyer-supplier relationships. Findings show use of effectuation can indeed enable a small, resource-restricted supplier to enter into a KAM relationship with a large retail customer. However, such use may lead to misrepresentation of capabilities. Indeed, contrary to extant literature (Sarasvathy, 2009), our study reveals the importance of location of resources, as lack of resource control led to development of suboptimal products and services. Given that a KAM relationship requires trust (Davies \& Ryals, 2014; Grandinetti, 2017) and presentation of a sub-optimal product within a KAM relationship is deemed a breach of trust (Mungra \& Yadav Prabhat, 2019), more causal decision-making processes may be appropriate when undertaking new product development within a Key Account Management relationship.

Furthermore, findings uncovered that continued attempts to recoup resources expended during KAM-based NPD activities through sale of rejected products to other customers failed, and consequently the small supplier further damaged its relationships with 
retailer customers. This created a cascading cycle of failure, each effectuation-led development depleting the small supplier's resources, requiring more effectuation to acquire more resources. In short, using effectuation by a small supplier to produce a 'not quite goodenough' product may lead to repeated, increasing, cascading sales failure, caused by involuntary breaches of customer trust.

As KAM is a dyadic relationship, failure holds the potential to affect both parties and indeed, their wider network (Hakansson et al., 2009; Håkansson \& Snehota, 2006). Accordingly, partner selection should include consideration of the decision-making logic of each party, a miss-match in which one party uses effectuation while the other uses causal logic, holding potential for relationship breakdown.

\subsection{Managerial implications}

For small suppliers managerial implications of the findings of this study make contributions in the small supplier-large customer KAM context. First by underlining the importance of listening carefully to requirements of the customer and understanding how much variance is likely to be acceptable (Friend et al., 2014). Indeed when using an effectuation-based approach, care should be taken by small suppliers to ensure sufficient and appropriate resources are available to meet exact requirements because effectual NPD that leads to an 'almost good-enough' product being developed may be deemed sub-optimal by the customer and can potentially be rejected.

Second, considering the position of a small supplier that expended resources to produce a sub-optimal product, further application of effectuation would suggest that because this is now what the small supplier has, it should be sold to recover expended resources (Sarasvathy, 2009). Assuming the product is safe and the small supplier deems it fit for purpose, this may appear reasonable. However, attempting to sell these sub-optimal products 
may bring short term success but also long term risk of leading to broken buyer trust, negatively impacting long term buyer-supplier relationships (Mungra \& Yadav Prabhat, 2019) and potentially impacting the small supplier's overall success.

Of course, a KAM is a dyadic relationship, which suggests both supplier and buyer are affected by the success. Therefore, for large customers managerial implications also make a contribution in the large firm-small supplier KAM context. These include identifying that care must be taken when considering entering into a KAM relationship with a small supplier to ensure they possess the required resources that are readily available. This will avoid the need for effectuation to be applied to acquire resources, which may negatively impact ability of the KAM partner to keep promises and deliver successful projects. If the project fails and the small supplier has heavily invested into it, this may create financial instability, which will have further negative consequences for the relationship. Therefore, managers of large customers considering a KAM relationship with a small supplier are advised to consider resource requirements and how capable their potential partner actually is. If there is potential for significant returns but the partner does not have sufficient resources, consideration should be given to supporting the small supplier to enable them to access what is required to successfully deliver the project.

For both small suppliers and large customers, there is therefore a need to consider the longer terms efficacy of effectuation, given that it would appear its use can be an antecedent to broken trust between buyer and supplier. This apparent link between use of effectuation and resultant breakdown of trust within a KAM relationship has not previously been identified, and use of effectuation in small supplier strategy would be a useful topic for initial large customer-small supplier discussions within a potential KAM relationship.

\subsection{Future research and final comments}


In addition to contributions made and practical managerial implications, there are also a number of implications for future research. For example, could there be more tolerance for failed NPD in the high technology sector? Future studies could also consider the impact of supplier maturity. In other words, does a small supplier "mature" in its thinking? And if it does, is that maturity reached in all processes at the same time? Additionally, could sales move to causal thinking while NPD continues to use effectuation? And, what impact would this have? These are all interesting potential future questions derived from this study.

The inevitable limitations of this paper also generate additional areas for future research. For example, it cannot be claimed that findings of just one case study represent all small supplier-large customer Key Account Management relationships. Such relationships exist within wider and more complex business networks (Hakansson et al., 2009; Håkansson $\&$ Snehota, 2006) than was readily accessible to the researchers during the course of this study. Therefore, future research could beneficially consider the impact of miss-matched decision-making within KAM relationships and how that may affect not only the actors directly involved, but also those within wider business networks (Hakansson et al., 2009; Håkansson \& Snehota, 2006). Furthermore, the case presented specifically concerns buyersupplier relationships within the food sector, making future research in other sectors of importance to test the wider applicability of the results obtained in this study. In addition, while this paper focused upon the relationship between a small supplier and large customer, it would also be interesting for future research to consider the impact of effectuation when used by firms of differing sizes, to explore relationships between effectuation strategies and firms size.

Via the research conducted, this study contributes new knowledge in the specific large-customer small supplier context. Specifically, use of effectuation by a small supplier to facilitate entry into a KAM relationship with a larger customer, may lead to involuntary 
breach of trust, subsequent attempts to recover lost resources through sales to other customers, leading to cascading cycles of sales failure. This also makes a contribution to managerial practice in that the apparent link between use of effectuation and a resultant breakdown of trust within a large customer-small supplier KAM relationship, not previously identified, makes use of effectuation in small supplier strategy a useful topic for initial large customer-small supplier discussions within a potential KAM relationship.

In terms of wider public policy, effectual buying and effectual selling clearly holds potential to facilitate firm creation (McGowan, 2018), facilitating economic development in deprived regions and developing countries. Indeed, in respect of the current COVID19 crisis, small firms "are tasked with the driving economic recovery globally, in contribution to economic growth" (Beynon, Jones, \& Pickernell, 2020, p. 15). The findings of this study suggest, however,a continuum relating to the efficacy of effectuation with too little use leading to missed opportunity and too much holding the potential for ethical transgression and growth restriction. Public policy needs to recognise this, so that a balanced view of its potential and limitations is given, to develop better understanding of why, when and how to switch from effectual to causal decision-making logic, to avoid overall sales failure.

\section{References}

Abosag, I., Yen, D. A., \& Barnes, B. R. (2016). What is dark about the dark-side of business relationships? Industrial Marketing Management, 55, 5-9.

doi:10.1016/j.indmarman.2016.02.008

Arli, D., Bauer, C., \& Palmatier, R. W. (2018). Relational selling: Past, present and future. Industrial Marketing Management, 69, 169-184. doi:10.1016/j.indmarman.2017.07.018

Berends, H., Jelinek, M., Reymen, I., \& Stultiens, R. (2014). Product innovation processes in small firms: Combining entrepreneurial effectuation and managerial causation. Journal of Product Innovation Management, 31(3), 616-635. doi:10.1111/jpim.12117

Cambra-Fierro, J. J., \& Polo-Redondo, Y. (2009). A relational approach of the supply function: an extension to the new ventures phenomenon in the small and medium enterprise 
(SME) context. Journal of Strategic Marketing, 17(5), 411-431.

doi:10.1080/09652540903216197

Chicksand, D. (2015). Partnerships: The role that power plays in shaping collaborative buyer-supplier exchanges. Industrial Marketing Management, 48, 121-139.

doi:https://doi.org/10.1016/j.indmarman.2015.03.019

Chowdhury, I. N., Gruber, T., \& Zolkiewski, J. (2016). Every cloud has a silver lining Exploring the dark side of value co-creation in B2B service networks. Industrial Marketing Management, 55, 97-109. doi:10.1016/j.indmarman.2016.02.016

Chung, H. F. L., Wang, C. L., Huang, P.-h., \& Yang, Z. (2016). Organizational capabilities and business performance: When and how does the dark side of managerial ties matter? Industrial Marketing Management, 55, 70-82. doi:10.1016/j.indmarman.2016.02.014

Cooper, R. G. (2018). The drivers of success in new-product development. Industrial Marketing Management. doi:10.1016/j.indmarman.2018.07.005

Cooper, R. G., \& Edgett, S. J. (2003). Overcoming the Crunch in Resources for New Product Development. Research-Technology Management, 46(3), 48-58.

doi:10.1080/08956308.2003.11671566

Cuevas, J. M., Julkunen, S., \& Gabrielsson, M. (2015). Power symmetry and the development of trust in interdependent relationships: The mediating role of goal congruence. Industrial Marketing Management, 48, 149-159. doi:10.1016/j.indmarman.2015.03.015

Dasanayaka, S. W. S. B., Al Serhan, O., Glambosky, M., \& Gleason, K. (2020). The business-to-business relationship: examining Sri Lankan telecommunication operators and vendors. Journal of Business \& Industrial Marketing, 35(6), 1069-1087. doi:10.1108/JBIM06-2019-0303

Davies, I. A., \& Ryals, L. J. (2014). The effectiveness of key account management practices. Industrial Marketing Management, 43(7), 1182-1194. doi:10.1016/j.indmarman.2014.06.007

Dew, N., Sarasvathy, S. D., Read, S., \& Wiltbank, R. (2009). Affordable loss: Behavioral economic aspects of the plunge decision. Strategic Entrepreneurship Journal, 3(2), 105-126. doi:10.1002/sej.66

Eisenhardt, K. M. (1989). Building theories from case study research. Academy of Management Review, 14(4), 532-550.

Eisenhardt, K. M., \& Graebner, M. E. (2007). Theory building from cases: Opportunities and challenges. Academy of Management Journal, 50(1), 25-32.

Ellegaard, C. (2006). Small company purchasing: A research agenda. Journal of Purchasing and Supply Management, 12(5), 272-283. doi:http://dx.doi.org/10.1016/j.pursup.2006.08.004

Ellegaard, C. (2009). The purchasing orientation of small company owners. The Journal of Business and Industrial Marketing, 24(3-4), 291-300. doi:10.1108/08858620910939831 
Fang, S.-R., Chang, Y.-S., \& Peng, Y.-C. (2011). Dark side of relationships: A tensionsbased view. Industrial Marketing Management, 40(5), 774-784.

doi:10.1016/j.indmarman.2011.02.003

Flyvbjerg, B. (2006). Five misunderstandings about case-study research. Qualitative inquiry, $12(2), 219-245$.

Friend, S. B., Curasi, C. F., Boles, J. S., \& Bellenger, D. N. (2014). Why are you really losing sales opportunities? A buyers' perspective on the determinants of key account sales failures. Industrial Marketing Management, 43(7), 1124-1135. doi:10.1016/j.indmarman.2014.06.002

Friend, S. B., \& Johnson, J. S. (2014). Key account relationships: An exploratory inquiry of customer-based evaluations. Industrial Marketing Management, 43(4), 642-658.

doi:10.1016/j.indmarman.2013.11.009

Frow, P., Payne, A., Wilkinson, I. F., \& Young, L. (2011). Customer management and CRM: addressing the dark side. Journal of Services Marketing, 25(2-3), 79-89.

doi:10.1108/08876041111119804

Goffin, K., Åhlström, P., Bianchi, M., \& Richtnér, A. (2019). Perspective: State-of-the-Art: The Quality of Case Study Research in Innovation Management. Journal of Product Innovation Management, 36(5), 586-615. doi:10.1111/jpim.12492

Grandinetti, R. (2017). Exploring the dark side of cooperative buyer-seller relationships. Journal of Business \& Industrial Marketing, 32(2), 326-336. doi:10.1108/jbim-04-2016-0066

Guenzi, P. (2003). Antecedents and consequences of a firm's selling orientation. European Journal of Marketing, 37(5/6), 706-727. doi:10.1108/03090560310465116

Guenzi, P., De Luca, L. M., \& Spiro, R. (2016). The combined effect of customer perceptions about a salesperson's adaptive selling and selling orientation on customer trust in the salesperson: A contingency perspective. Journal of Business \& Industrial Marketing, 31(4), 553-564. doi:10.1108/JBIM-02-2015-0037

Hakansson, H., Ford, D., Gadde, L. E., Snehota, A. W. I., \& Waluszewski, I. (2009). Business in networks. In. Chichester: John Wiley \& Sons.

Håkansson, H., \& Snehota, I. (2006). No business is an island: The network concept of business strategy. Scandinavian Journal of Management, 22(3), 256-270.

Heidenreich, S., Wittkowski, K., Handrich, M., \& Falk, T. (2014). The dark side of customer co-creation: Exploring the consequences of failed co-created services. Journal of the Academy of Marketing Science, 43(3), 279-296. doi:10.1007/s11747-014-0387-4

Heidenreich, S., Wittkowski, K., Handrich, M., \& Falk, T. (2015). The dark side of customer co-creation: exploring the consequences of failed co-created services. Journal of the Academy of Marketing Science, 43(3), 279-296. doi:10.1007/s11747-014-0387-4

Hingley, M. K. (2005). Power imbalanced relationships: Cases from uk fresh food supply. International Journal of Retail \& Distribution Management, 33(8), 551-569. doi:doi:10.1108/09590550510608368 
Ivens, B. S., \& Pardo, C. (2007). Are key account relationships different? Empirical results on supplier strategies and customer reactions. Industrial Marketing Management, 36(4), 470482. doi:http://dx.doi.org/10.1016/j.indmarman.2005.12.007

Ivens, B. S., \& Pardo, C. (2016). Managerial implications of research on inter-organizational interfaces: The case of key account management. IMP Journal, 10(1), 25-49.

doi:doi:10.1108/IMP-06-2015-0030

Johnson, J. S., Friend, S. B., \& Malshe, A. (2016). Mixed interpretations of sales proposal signals. Journal of Personal Selling \& Sales Management, 36(3), 264-280.

doi:10.1080/08853134.2016.1205447

Kester, L., Griffin, A., Hultink, E. J., \& Lauche, K. (2011). Exploring Portfolio DecisionMaking Processes*. Journal of Product Innovation Management, 28(5), 641-661. doi:10.1111/j.1540-5885.2011.00832.x

La Rocca, A., Moscatelli, P., Perna, A., \& Snehota, I. (2016). Customer involvement in new product development in B2B: The role of sales. Industrial Marketing Management, 58, 4557. doi:https://doi.org/10.1016/j.indmarman.2016.05.014

Langley, A. (1999). Strategies for theorizing from process data. Academy of Management Review, 24(4), 691-710.

Liu, Y., Huang, Y., Luo, Y., \& Zhao, Y. (2012). How does justice matter in achieving buyersupplier relationship performance? Journal of Operations Management, 30(5), 355-367. doi:http://dx.doi.org/10.1016/j.jom.2012.03.003

McGowan, P. (2018). The impact of effectuation on small firm buying decisions. IMP Journal, 12(3), 444-459.

McGowan, P. (2020a). Sales failure: a review and future research directions. International Journal of Logistics Research and Applications, 1-28. doi:10.1080/13675567.2020.1726306

McGowan, P. (2020b). Use of effectuation by established micro businesses: short-term gain, long-term pain? Journal of Business \& Industrial Marketing, ahead-of-print(ahead-of-print). doi:10.1108/JBIM-01-2020-0055

McKelvie, A., Chandler, G. N., DeTienne, D. R., \& Johansson, A. (2019). The measurement of effectuation: highlighting research tensions and opportunities for the future. Small Business Economics. doi:10.1007/s11187-019-00149-6

Meehan, J., \& Wright, G. H. (2011). Power priorities: A buyer-seller comparison of areas of influence. Journal of Purchasing and Supply Management, 17, 32-41.

doi:10.1016/j.pursup.2010.05.002

Meredith, J. (1993). Theory building through conceptual methods. International Journal of Operations \& Production Management, 13(5), 3-11.

Miles, M. B., \& Huberman, A. M. (1994). Qualitative data analysis: An expanded sourcebook: sage. 
Morgan, T., Anokhin, S., Kretinin, A., \& Frishammar, J. (2015). The dark side of the entrepreneurial orientation and market orientation interplay: A new product development perspective. International Small Business Journal, 33(7), 731-751.

doi:10.1177/0266242614521054

Morrissey, W. J., \& Pittaway, L. (2004). A study of procurement behaviour in small firms. Journal of Small Business and Enterprise Development, 11(2), 254-262.

doi:doi:10.1108/14626000410537191

Morrissey, W. J., \& Pittaway, L. (2006). Buyer-supplier relationships in small firms: the use of social factors to manage relationships. International Small Business Journal, 24(3), 272298. doi:10.1177/0266242606063433

Mungra, Y., \& Yadav Prabhat, K. (2019). The mediating effect of satisfaction on trustcommitment and relational outcomes in manufacturer-supplier relationship. Journal of Business \& Industrial Marketing, 35(2), 219-230. doi:10.1108/JBIM-09-2018-0268

Nag, R., Hambrick, D. C., \& Chen, M. J. (2007). What is strategic management, really? Inductive derivation of a consensus definition of the field. Strategic Management Journal, 28(9), 935-955.

Oliveira, N., \& Lumineau, F. (2019). The Dark Side of Interorganizational Relationships: An Integrative Review and Research Agenda. Journal of Management, 45(1), 231-261. doi:10.1177/0149206318804027

Ortega, A. M., García, M. T., \& Santos, M. V. (2017). Effectuation-causation: What happens in new product development? Management Decision, 55(8), 1717-1735. doi:10.1108/md-032016-0160

Piekkari, R., Plakoyiannaki, E., \& Welch, C. (2010). 'Good'case research in industrial marketing: insights from research practice. Industrial Marketing Management, 39(1), 109117.

Read, S., Dew, N., Sarasvathy, S. D., Song, M., \& Wiltbank, R. (2009). Marketing under uncertainty: The logic of an effectual approach. Journal of Marketing, 73(3), 1-18. doi:10.1509/jmkg.73.3.1

Roach, D. C., Ryman, J. A., \& Makani, J. (2016). Effectuation, innovation and performance in SMEs: an empirical study. European Journal of Innovation Management, 19(2), 214-238. doi:10.1108/ejim-12-2014-0119

Runyan, W. M. (1982). In defense of the case study method. American Journal of Orthopsychiatry, 52(3), 440.

Sarasvathy, S. D. (2001, 2001/08//). Effectual reasoning in entrepreneurial decision making: Existance and bounds.

Sarasvathy, S. D. (2009). Effectuation: Elements of entrepreneurial expertise. Cheltneham UK: Edward Elgar Publishing.

Schiele, H. (2012). Accessing supplier innovation by being their preferred customer. Research-Technology Management, 55(1), 44-50. doi:10.5437/08956308X5501012 
Skinner, D., Dietz, G., \& Weibel, A. (2014). The dark side of trust: When trust becomes a 'poisoned chalice'. Organization, 21(2), 206-224. doi:10.1177/1350508412473866

Terho, H., Eggert, A., Haas, A., \& Ulaga, W. (2015). How sales strategy translates into performance: The role of salesperson customer orientation and value-based selling. Industrial Marketing Management, 45, 12-21. doi:https://doi.org/10.1016/j.indmarman.2015.02.017

Villena, V. H., Revilla, E., \& Choi, T. Y. (2011). The dark side of buyer-supplier relationships: A social capital perspective. Journal of Operations Management, 29(6), 561576. doi:10.1016/j.jom.2010.09.001

Webb, J. W., Ireland, R. D., Hitt, M. A., Kistruck, G. M., \& Tihanyi, L. (2011). Where is the opportunity without the customer? An integration of marketing activities, the entrepreneurship process, and institutional theory. Journal of the Academy of Marketing Science, 39(4), 537-554. doi:10.1007/s11747-010-0237-y

Weitz, B. A., Sujan, H., \& Sujan, M. (1986). Knowledge, motivation, and adaptive behavior: A framework for improving selling effectiveness. Journal of Marketing, 50(4), 174-191.

Woschke, T., Haase, H., \& Kratzer, J. (2017). Resource scarcity in SMEs: effects on incremental and radical innovations. Management Research Review, 40(2), 195-217. doi:doi:10.1108/MRR-10-2015-0239

Wu, L., Liu, H., \& Su, K. (2020). Exploring the dual effect of effectuation on new product development speed and quality. Journal of Business Research, 106, 82-93.

doi:10.1016/j.jbusres.2019.09.016

Yin, R. K. (1994). Discovering the future of the case study. Method in evaluation research. Evaluation practice, 15(3), 283-290.

Yin, R. K. (2009). Case Study Research: Design and Methods (4th ed.). London: Sage.

\section{Appendix A: Interviewees}

\begin{tabular}{|l|l|l|}
\hline \multirow{4}{*}{$\begin{array}{l}\text { Small supplier: } \\
\text { Snack Foods Brand }\end{array}$} & $\begin{array}{l}\text { Job Position } \\
\text { Onterviews }\end{array}$ \\
\cline { 2 - 3 } & $\begin{array}{l}\text { I1) Chief marketing officer UK (joined } \\
\text { 18 months into research project) }\end{array}$ & 5 \\
\cline { 2 - 3 } & $\begin{array}{l}\text { I2) Head of marketing (left company 19 } \\
\text { months into research project) }\end{array}$ & 4 \\
\cline { 2 - 3 } & I3) Chief executive officer UK & 11 \\
\cline { 2 - 3 } & I4) Chief operating officer UK & 13 \\
\cline { 2 - 3 } & $\begin{array}{l}\text { I5) Former head of sales and sales agent } \\
\text { for Retailer A (left company 21 months } \\
\text { into research project) }\end{array}$ & 6 \\
\cline { 2 - 3 } & $\begin{array}{l}\text { I6) Head of sales and key account } \\
\text { manager for Retailer A (joined company } \\
\text { 22 months into research project) }\end{array}$ & 2 \\
\hline & I7) Key account manager for Retailer B & 2 \\
\hline & $\begin{array}{l}\text { I8) Former head of NPD (left company } \\
\text { 30 months into research project) }\end{array}$ & 12 \\
\hline
\end{tabular}




\begin{tabular}{|c|c|c|}
\hline & $\begin{array}{l}\text { I9) Head of NPD (joined company } 33 \\
\text { months into research project) }\end{array}$ & 2 \\
\hline \multirow{3}{*}{$\begin{array}{l}\text { KAM Partner: Top } \\
\text { three UK } \\
\text { supermarket retailer, } \\
\text { in terms of market } \\
\text { share }\end{array}$} & I10) Head buyer snack foods category & 2 \\
\hline & $\begin{array}{l}\text { I11) Associate buyer snack foods } \\
\text { category }\end{array}$ & 1 \\
\hline & $\begin{array}{l}\text { I12) Category manager responsible for } \\
\text { snack foods }\end{array}$ & 1 \\
\hline \multirow{2}{*}{$\begin{array}{l}\text { Retailer B: Leading } \\
\text { European health } \\
\text { food retailer }\end{array}$} & $\begin{array}{l}\text { I13) Head buyer for snacks and sports } \\
\text { nutrition }\end{array}$ & 2 \\
\hline & I14) Marketing manager & 1 \\
\hline $\begin{array}{l}\text { Independent retailer } \\
\text { (C) with five stores }\end{array}$ & I15) Head buyer & 1 \\
\hline $\begin{array}{l}\text { Independent retailer } \\
\text { (D) with four stores }\end{array}$ & I16) Buyer & 1 \\
\hline
\end{tabular}

